つたとの報告であった。後者は 5 段階に調節可能な可変 レンズ絞り機構を用いて，絞りサイズを変えた場合に $\mathrm{TV}$ モ二夕像の評価, 被曝線童の減少度合い, 臨床評価が どうなるかについての報告であった。二者ともスーバ I.I. と可変絞りの組み合わせシステムが非常に有効であ ると報告した。

質問 （森） I.I.はどちらも新品か，また線跬を約 $1 / 2$ に低減できたとのことだがそのときの絞り值は？

答（千葉）絞りは従来 I.I. が $25 \mathrm{~mm} \phi$, スーパ I.I. は $20 \mathrm{~mm} \phi$ である。

演題441は I.I. の輝度劣化は, 被写体コントラストの低 下や被曝線量の増加につながるため，追跡調査が重要で ある，今回設置時期の異なる 2 台の I.I.で輝度測定とテ ストカセッテで管電圧を測定した結果を報告した。

質問（宇都 近畿大）テストカセッテの信頼性は。 答（荒木） カセッテ自体の信頼性は調べていない。 別の基準測定器で校正すべきと思う.

演題442はJISで定められている I.I. の輝度測定で用 いられている輝度計の代わりに CCD カメラとマイコン を接続したシステムを製作し，良好な基礎的データを得 た。本システムでI.I.の日常管理が容易にできると考え る。今後有用性を確かめたいと報告した。

質問 （森） $\mathrm{CCD}$ のコスト，また $\mathrm{Gx} の$ 測定は可能 か.

答（千田）マイコンなどを含んだコストは輝度計と 同程度である，Gxの測定は輝度計との関係を把んでお れば可能と思う。

諸特性が改善されたI.I. は冠状動脈造影やPTCA ぞ高 $\mathrm{kV}$, 高線量の透視・撮影時にその特長が発輝される と考える。一層の性能改善を期待したい.

医療被曝の軽減に努力することは，放射線技師の使命 であり，特に小肾の場合は十分な配慮がなされるべきで ある。他山の石とし，日常業務の中で実践して欲しい.

経時的 I.I. の輝度測定は I.I. の交換・廃弃時期を決定 するための説得力あるデータになるだろう。今後さらに 多くの施設で測定が実施され，メーカとユーザが協力し てデータを集積し, 近い将来, 本学会としての交換・廃 棄基準が作成できるならば，一般会員に資するところ大 であると考える。最後に各演者のますますの御研鑽を祈 って本セッションのまとめとする.

DSA 装置-1（演題番号36～40）

新開英秀（九州大学医学部附属病院） この演題群はDSA 装置の開発研究に関するもの 3 題
DSA の濃度情報に関する基礎的研究 1 題，DSA 撮影法 の研究 1 題の 5 題の演題群である.

演題36は，画像デー夕をリアル夕イムで記録する高速 大容量ディスクシステムを開発したという報告である。

第43回総会で福西（国立循環器）は，ほぼシネと同程 度の解像力が得られ，肺静脈還流異常や冠動脈の横隔膜 下の血管像の解析など DSAの方が優れていると報告し たが，通常の左心室，冠動脈検查ではディスク 4 台に 8 人分のデータが記録可能であることを考えるとシネ撮影 がDSAに扔きかえら机る日もそう遠くない気がする。

演題37は, PTCA 検査時, VTRやVDR を用いて TV モニタ上に静止画像を表示させることは必要な機能であ るが，VTRは検索に時間を要し，VDR は録画可能時間 が短い等問題が多い。そこでデジタル・ビデオ・メモリ 一装置 (VM) を利用寸ることにより，画像処理が可能で ある点も考え，将来的にはPTCAに㧍いてVMに光童 を今よりも十分に（現在 $9 ： 1 ）$ 与えることにより，シ ネに代わりうると考えているとの報告である。

演題38は，手術時の検査として外科用イメージに取り つけDSA ができるようにした装置で，18枚の撮影が 3 回可能である装置の試作についての報告である。手術時 の経過を観察するための装置で，3回の撮影で十分なの か，多少問題もあるような気もするが，その必要性につ いてはよく理解できる。

工藤 (大阪市大) より，通常の血管造影室での DSA と 手術場にて行うDSAに手技的に差異があるかとの質問 に対し，差程ないとの回答であった。

演題39は, DSA の場合散乱線や I.I.のベーリンググレ ア等のため, 血管径や造影剤濃度に比例した濃度情報が 得られないため,これらの要因についての検討である。 これらの要因のうちベーリンググレアの影響が最も大き く, 高電圧の使用, 補償フィルタの利用により被写体コ ントラストが低下し，その影響が減少したとする報告で ある。

東田 (熊大)よりDSA の特性曲線については，どれ位 のダイナミックレンジがあれば良いと考えるかとの質問 に対し，より広いダイナミックレンジがあれば使用しや すいのは当然であるが，フィルム系と同程度のダイナミ ックレンジがあればよいとの回答であった。

演題40は, DSA の問題点の一つである観察視野の問題 を, 造影剤注入後モニ夕観察しながら，テーブルを動か してその画像をデジタルディスクに保管し, ポストプロ セスにてサブトラクションを行ったという報告である。

鈴木（帝京大）より，モニ夕観察にて血管像を追跡し 
手動にてテーブルを動かすをき，モニタにて血管像が観 察されるのであ礼ば，サブトラクションの必要もないの ではないかという意見も约されたが，膝召動脈以下の血 管中の造影剤濃度は，数\%程度に希勫されるが，その場 合のDSAによるコントラスト分解能の们上は䧐断的意 義も深く，側副血行路の血管もDSAにて観察可能とな るであろう。

この報告は手動でテーブルを動かしたが moving table 存使用した方法として第13回秋季学術大会にて堀 部 (名古屋大分院)，日放技学誌 43 卷 9 器にて加藤（香川 医科大）に上り報告されている。

1980年11月北米放射線学会でDSA 装置が発表されて 以来，飛躍的にアップグレードされてきた。また撮影技 術も，学会員のた妕ま好努力で侵旁の少ない検査と位圆 づけされてきた。今後ともなお一層の研究開発が必要で あり，会員諸兄の努力に待期したい。

DSA 装置- 2 （演題番镐41 45）

「藤弘明（大阪㭪大病院）

DSA 装置- 2 ，演題41〜 45はDSA 補償つィルタに関 するものであるが，演題450「DSAに扔ける経時的フィ ルタが Hemodynamicsに及棌す影留」はフィルタと盖

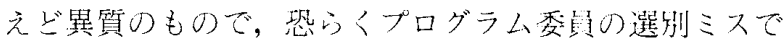
あるう。

まず，演題410「DSA用シュミレーションモニ夕の開 発（1報）」で奈良矤大の吉岡らはDSA 検㮅本番前に行 うX線テストパルスで得られた画像を TVモニ夕はへ フリーズし，画像上のハレーション部在叮朔性:フィルタ

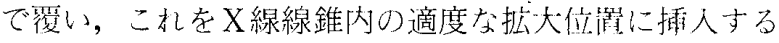
と言う方法で，技師の被曝がなく，簢単・过速・此確に 補償フィル夕の作成，插入が行えた，と言う報告である。 現在のDSA 補償フィル夕挿人法は定形のアルミ，增感 紙などを透視下にて插入すると言う原始的で繁雑な方法， 作業である。この点, 演者らのアイデアは素晴らしく， 臨床の場で極めて有用と考える。

次に，演題420「DSA 補償フィル夕朋シュミレーショ

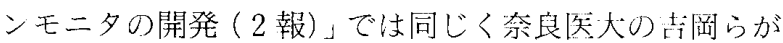
先程の演題41の画像を通常の形でディスプレイするので はなく，可塑性フィル夕を形成し易く寸る目的でハレー ション部を多段階表示したと言う報告である。ハレーシ ヨン領域が明らかになるとともにハレーション部の形状 予測が可能になり，よりフィル夕作製が容易になると思 わ扎る。このように演題 $41 ， 420$ 方法が今後の主流にな ると思わ礼る。
演題43の「DSA 補償フィルタ（ビニルシリコン材の利 用)」では佐賀医大の廣木らがビニルシリコン材を用い各 種形状の DSA 補償フィルタを作製すると言うもので, 使用した材料は加工が容易で破損し難く，補償フィル夕 に良好な材料であると報告した。

演題44の「Unsharp Masking Film のDSAの応用に 対する基礎的検討」では藤田学園の木野村らが DSA 補 償フィルタの插入についてX線線錐内でなくI.I. を通過 した光量で濃度補償させるもので，実際には頭部正面像 のハレーションを押える平均的な光学フィル夕を作製， ディストリビュータ内に押入していた。これら結果は今 一つの感があるが，極めてユニークでありDSAについ て常に考えてないと及びもつかない方法である，今後の 改良, 発展に大いに期待したい.

演題45の「DSAにおける経時的フィルタが hemodynamicsに及济す影響」では宝塚市立病院の岡野らが画 像積分, リカーシブルフィルタは血流解析に扔いて濃度 情報に偽情報が含まれタイムデンシティーカーブの形状 が変化，誤差の原因となることを指摘した。

以上 5 演題を通し各施設ともDSA 補償フィル夕に苦 労しているのが良くわかる，今回，実用に供する報告が あったのが大きな収穫であった．演者の方々の今後の発 展を祈ります。

\section{CR 装置（演題番号51～56）}

\section{菅野由紀雄}

(国家公務員等共済組合連合会虎の門病院放射線部) この演題群は CR 装置である。

演題51は一般撮影室の全面 CR 化の報告である。三原 らは去年の秋季学術大会 (浜松)でも全面 CR 化に抢ける 実用的な改良点を発表している。今回の報告ではさらに 効率的に抢こなうためX線制御装置と CR のコンソール を…体化等の必要性を説いた。メーカは現場の声として このことに関しても企業努力をして戴きたい. 演題52〜55は CR7000システムの報告である.

質問（藤田 岐皁工専）(1)旧システムと比較して高 線量になるほど，新システム固有ノイズが改良されてい るが具体的に改良されたところはどこか. (2)レーザープ リンタの MTFの測定方法を教えてほしい.

答（木村）(1)主にIPの構造モトルを改良した。

答（大原）(2)矩形波チャートを用いておこなった。

質問（三代 独協医大） (1)ビームの楕円化は主走查 方向に対して長軸の棈円か. (2)その効果は. (3)棈円の形 状を選んだ理由は。たとえば矩形のほうがレスポンスが 